ation, the institution which insures our lives, mas put a promium upon poisoning; and that the profession which is to rancese from disease and death may be adulterated with mien who will lend their signatures, heedless whether their own ranks be adulterated with the presence of a poisoner." It is, we confess, difficult to get either sense or grammar out of this sentence; we can, however, dimly see that a slur is cast upon the whole Medical profession, on account of the acts of one mau, who, though legally, was certainly not practically, a surgeon. As well might all the clergy be denounced, because ministers have been known to have lived profligate lives; or the press itself, because several of its members have been transported for seditious publications.

\section{HISTORY OF THE JOURNAL.}

\section{By W. A. GREENHILI, M.D.}

[Conctuded from page 14.]

The Anniversary Meeting at Oxford in 1852 was the most important in its consequences of any that had hitherto taken place ; whether it was important for good or for evil is still a disputed point, which need not be discussed here. It is neces. sary to bear in mind the dates of the different events that occurred.

On May 5th, Dr. Cowan gave notice that he intended to move at the next Anniversary Meeting, "that the Provincial Medical and Surgical Journal be published weekly, and that it be edited and published in London." (Ibid., pp. 3:J2, 437.) This notice was clearly informal, inasmuch as the 19th of the old code of laws required " that any member wishing to propose a new lav or an alteration in an existing law, must send notice of his intention to the Secretary three months previous to the Anniversary Meeting "The informality was, however (whether designedly or not), overlooked; and Dr. Cowan's notice of motion was (as the law directed) appended to the Report of the Conncil, and circulated with it. A leading article on the sub. ject of Dr. Cowan's motion appeared in the Journal on June 9th, another on June 2:3rd, and a third on July 7th; but neither of them makes any allusion to the informality with respect to time, which was not brought forward in the Journal till after the decision of the Anniversary Meeting on July the 21st and 22nd.

The subject of Dr. Cowan's motion was discussed at several of the Branch meetings held prior to the Anniversary Meeting.

At the North Wales Branch meeting, June 15th, and also at the Lancashire and Cheshire Branch meeting, June 30th, there was a difference of opinion, and no resolution was come to. (Ibid., pp. 346, 368.)

At the Suffolk Branch meeting, June 25th, the members « were anxious to convey their united sentiments and wishes that the editorship and publication of the Provincial Medical and Surgical Journal be continued under its present arrangements, to which their entire concurrence is unreservedly given." (Ibid., p. 353.)

At the meeting of the South.Eastern Branch, June 3nth, it was unanimonsly carried, " that, without wishing to fiud fault with the Editors of the Journal, and without expressing any positive opinion as to the merits of Dr. Cowan's plan, this meeting feels strongly that the conduct of the Journal requires improvement, and, therefore, begs earnestly to press this subject npon the attention of the General Meeting at Oxford." (Ibid., p. 451.)*

At the meeting of the Shropshire Branch, July 8th, it was decided "that this Branch strongly deprecates any alteration in the editorship or publication of the Provincial Medical and Surgical Journal, and considers that the present Editors are deserving of the best thanks of the Association." (Ibid., p. 379.)

The Report of the Council presented at the General Meeting contained a recommendation " to appoint a Committee of mem-

- By a singular coincidence, this, which was the only resolntion adverse to the Journal that was passed at any of the branch meetings, was also the only one that was not inserted in the Journal prinr to the Oxford meeting whereby whatever degree of influence it might ut!lerwise have exercised was almost wholly destroyed. bers, to take into consideration any suggestions that may be made for improving the publications, and especially as to the editorship of the Journal." (Ibid., p. 39j.) Dr. Cowan brought forward his motion, " that in future the Jourmal be edited and published in London, and that it be published reekly, instead of fortnightly, as at present." An animated debate ensued, and, as an amendment, it was moved, " that a Comnittee be appointed, with full power to cousider such changes as might be necessary in the management of the Journal, and to carry the same into effect in 1853." The result may (for the moment) be told in the words of the reporter, though his account will be found to require correction in two important particulars. "The President then put the amendment, in the usual way, by a show of hands, but the members appeared to be so equally divided, that it was urged there should be a poll; an attempt was aceordingly made to take one, but in consequence of the confusion which ensued, it proved unsuccessful. It was then suggested that those in favour of the amendment should sit on the left of the chair, and those opposing it, on the right; and that the respective numbers should be ing it, on the right; and A number of gentlemen who declined to vote either way retired to the adjoining room. The result was as follows :-

$$
\begin{aligned}
& \text { "For the amendment } . \ldots \ldots \ldots \ldots \ldots, \ldots
\end{aligned}
$$

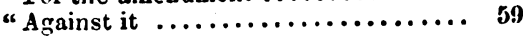

$$
\begin{aligned}
& \text { “ Majority .................... }
\end{aligned}
$$

"The announcement of the numbers was received with much applause, and an exciting scene ensued; and in the midst of the confusion attendant on this, the President declared the original motion (zohich had not been formally put to the meeting) carried..... A Committee, consisting of eight or nine gentlemen was understood to be appointed, though the proceedings were here extremely confused, and the appointment, if made at all, was done in a most irregular manner." (Ibid., p. 308.) 1). Kanking at once resigned his post as one of the Editors : Mr. Walsh consented to continue his services till the end of the year.

Several changes took place in the constitution of the Journal Committee; the members who finally agreed to act were Drs. Cowan, Edwards, Greenhill, and George Webster, and Mr. Hunt.

In the same number of the Journal that contained the account of the Oxford meeting (Aug. 4th), there appeared also a leading article, in which it was stated that Dr. Cowan's original motion had not been carried, and that, therefore, "we were just as if nothing had been done at Oxford, quoad the change of place for pululication." (Ibid., p. 409.) This assertion drew for a letter from the President, Dr. Ogle, in which he " un hesitatingly avers that the original motion was put to the meeting :" he adds that, at the time of voting, he "directed that those who supported the amendment should take seats on the one, and those who were for the original motion on the other side of the house;" that "no one objected to the arrangement he proposed," and that " motions were subsequently made, and carried, which implied the concurrence of all parties in the declaration made from the chair, that the original motion was carricd; among them was that of the appointment of the [Journal] Committee,.... which.... was not merely ' under stood' to be appointed, but was regularly put to the rote, and confirnicd." (Ibid., p. 436 .)

In the same number of the Journal that contains this letter (August 18th), there appears another leading article, in which it is stated that, " after attentively examining Dr. Ogle's communication, we are more than ever convinced of the informality of the proceedings relative to the Journal at Oxford," and that "the above letter fully hears ont our assertion that "we are just as if nothing had been done at Oxford, quoad the change of plan of publication." (Ibid., p. 437.)

Probably the effect of Dr. Ogle's letter upon the minds of most readers was different from what is here stated. The Council, however, were confirmed in the opinion expressed in the Journal, viz." "that the members generally were not bound by the proceedings at Oxford," by the discovery of another informality, which had been previously overlooked. "Dr. Cowan's notice of motion was not given, as required by Rule 19, three months before the Anniversary Meeting. It appears that the Anniversary Meeting was officially announced in this Journal on March 31st, nearly four months before the meeting at Oxford, while Dr. Cowan's notice was not sent till May 5th, so that there cannot be the slightest doubt that the whole proceedings based upon it are contrary to law." (Ibid., p. 43\%.) 
For some weeks a correspondence was carried on between the Council and the Journal Committee, but the letters that passed on the subject have not been published.

On September 3rd, a special moeting of the Bath and Bristol Council was held, "to consider if any, or what steps should be taken by this Branch to support the resolution relating to the Journal, passed at the Oxford Meeting," and it was resolved nnanimously - I, "that, notwithstanding certain informalities occurred in putting the resolutions touching the future conduct of the Journal to the Oxford Meeting, yet, as no objection was made at the time to the course of the proceedings, these resolutions must be cousidered as passed and binding on the Asso. ciation " and 2 , "that the objection taken by the Central Council to the notice given by Dr. Cowan, with reference to the alteration of the Journal, is untenable, because that notice was adopted by the Central Council, and circulated by them to the members of the General Council, and was adopted and acted on by the meeting at Oxford as legal and regular." (Ibid., p. 475.)

Probably these resolutions expressed fairly enough the opinion of the wajority of the members on this subject; and, accordingly, on September 11th, it was resolved unanimously by the Central Council, that, " having ascertained from many influential members of the Association that the general feeling is in favour of the validity of the resolution passed at Oxford with regard to the Journal, they are of opinion that it is not desirable further to insist unon the informality of Dr. Cowan's proposition." (Ibid., p. 489.)

No further opposition was made to the removal of the Journal from Worcester to London.

The account of this matter, which was afterwards given by the President of the Council, is as follows:-" After the Oxford meeting, the Executive Council had their attention called to some informality* in the proceedings relative to the resolution touching the Journal, that was passed at that meeting. Seeing that the resolution had been carried by so sinall a majority as two, the Council considered ther should not properly perform their duty if they did not fairly settle the question, so as to place it beyond future cavil. The Council, there fore, through the Journal, and by correspondence, apperled to the members as to the validity of the objection taken liy them. The reply being to the effect, that, although there was manifestly some irregularity in the proceedings, yet that the decision should be final, the Council acquiesced in that view, and on September 1lth, seven weeks after the Oxford Meeting, they met and resolved," etc. [Here follows the resolution given above.] "No opposition was afterwards offered by the Council to the Joumal Committee." (Association Medical Joumal, 1855, p. 1000.)

In a leading article that lately appeared in the Jouvnal, it is stated, that " when it was carried at the Oxford meeting by the barest possible majority that the Journal of the Association should be transferred to London.....that decision was immediately acquiesced in by the President, and cheerfully carried out by the Executive Conncil." ( Moid., p. 95?.)

The details given above (if fairly stated) will enable each member to form an opinion for himself as to how far these words are applicable to an opposition which did not cease till seven weeks after the Oxford meeting. The Chairman of the Journal Committee sent a short letter the following week to the Journal, saying that this statement respecting the Executive Council was "so directly at variance with truth, and so calculated to convey a false impression as to the nature of the present agitation, that .... he begged to give it a distinct contradiction"; and that, "instead of "cheerful acquiescence', the most determined opposition was encountered, which only reased to be actively exerted when the publication of the correspondence was threatened." (Ibid., p. 981.) The Editor Dr. Wynter) immediately and frankly confessed his "ignorance as to what passed behind the scenes consequent npon the Oxford vote", and explained that "the impression he intended to convey .... . was, that no public proceedings were taken by the minority on that occasion calculated to injure the Association,"-in other words, that the "immediate acquiescence" and "cheerful carrying out" belonged to the members at large, and not to the Executive Council and the President.

With respect to the removal of the Journal from Worcester, it need only be added that on August 26th, at a meeting of the South Wales Branch, a resolution was passed unanimously ex-

- It is not quite clear which of the two informalities is here alluded to. It - It is not quin was called to these informalities. pressive of regret at the proposed change (Prov. Med. and Surg. Journal, 1852, p. \$81); and that Dr. Cormack was appointed Editor of the Journal, with the same salary that had hitherto been divided between the two conjoint Editors, viz., \$250 a-year. Several letters on the subject appeared in the Journal, an address from the Journal Committee, and s sensible and temperate leading article, coutaining some useful suggestions resulting from the Editor's (Mr. WValsh's) own experience, and warning the members "that, unless they did their best to increase the funds, by obtaining new members, the Societs would be speedily swamped by a load of debt." (Ibid., p. 512.) But the Editor was only a "prophet of evil", and his words were as one of Cassandra's warnings

At the beginning of 1853 , the Journal made its appearance as the Astock in London, price $i d$. stamped. The usual size was to be twentyfour pages, and a larger sheet to be occasionally afiorded. (As8oc. Jed. Journal, J853, p. 22.)

The events that have occurred since that time may be noticed very briefly, as being fresh in the memory of all the members. In 1853, at the Anviversary Meeting at Swansea, it was stated in the Report of the Council that, " in all probability, the Traneactions would not be continued", on account of the large expenditure of the Journal.

In 185:-3, the 'Transactions and General Priuting Account cost $\mathcal{E} 334$, the Provincial Journal (for six months) $\mathfrak{E 2 5}$, and the Association Journal (for six months) $£ 928$, with an unpaid balance of \$*378. (Ibid., p. 7\%6.) A more detailed financial statement of the Journal was drawn up by the Editor, and preseuted by the Journal Committee, and gave rise to considerable discussion.

In February 1854, Mr. Sheppard, the Secretary to the Association, died. In justice to his memory, it should be stated, that, by his active exertions, he reduced the amount of the arrears of subscriptions by more than $\$ 500$ (compare Prov. Med. and Surg. Journal, 1849, p. 427, with Assoc. Med. Journal, 1854 , p. 852 ), though he was obliged to leave more than $£ 1,300$ to be collected by his successor.

In March, Dr. Williams was appointed by the Central Conncil to act as Secretary " until the next Annual Meeting." (Ibid., 1851, p. 23:.)

At the Anniversary Meeting at Manchester, Dr. Cormack was appoir.ed Secretary, in the place of Dr. Williams. In the Report of the Council, the total cost of the Journal, 1853.4, is stated to have been $\mathfrak{£} 1,541$, with an unprid balance of $£ 1,1 ; 1$. (Ibid., p. 852.) In the statement of accounts for the year 1853, presented by the Journal Committee, the total cost of the Journal is reckoned at $\mathcal{E}^{2}, \mathbf{6 0 5}$, with an unpaid balance of £1,090. (Ibid., p. 855.) A long discussion took place on the state of the finances of the Association.

At the York Meeting, 1855, in the Report of the Conncil, the total cost of the Joumal in the year 1854 is said to have been $\mathcal{E}^{2}, 309$, with an unpaid balance of $£ 1,457$. (Ibid., 1855, page ij6.) In the statement of Journal account for the same period presented by the Editor, the expenses of the Journal are reckoned at $£_{2}, 678$, with the same amount of liabilities, which were reduced by June 30 th to $£ 950$. (Ibid., p. 779.)

This is not the place to attempt to reconcile the apparent discrepancies in the financial statements that have been laid before the Association, nor to estimate and explain the real amount of inconsistency that exists between the actual cost of the Journal and Dr. Cowan's estimate at Oxford; but any one who would investigate these two points, and make known the result in a plain and intelligible form, would certainly be doing good service to all parties.

To complete this sketch of the history of the Journal, it only remains to add, that, at the York Meeting, Dr. Williams was sppointed Secretary, in the place of Dr. Cormack, that shortly afterwards Dr. Cormack resigned the Fiditorship, and that at the beginning of October, out of fourteen candidates for the vacant office, Dr. Wynter was elected Editor by the Executive Council." (Ibid., p. 917.) Probably all persons will admit (in general terms) that the Journal was improved under Dr. Cormack's management, while it is incontestable that his exertions, both as Secretary and as Editor, considerably reduced the amonnt of arrears of subscriptions, and added several hundred members to the Association.

- With respect to the change of name, it may be remarked, that the mean. "With respect to the change of name, it may be remarked, that the mears
ing of the new name is uot very clear (as the epithet "medical" appears to be in the wrong place), nor is the object in making the change any whore explalued, neither is in 